\title{
Financial Constraints and Financial Crises: The Case of Portuguese Listed Companies
}

\author{
Luísa Pereira ${ }^{1}$, Armando Silva $^{2} \&$ Sónia Nogueira Silva ${ }^{3}$ \\ ${ }^{1}$ Instituto Politécnico do Porto, ISCAP \\ ${ }^{2}$ Instituto Politécnico do Porto, ISCAP and CEFUP \\ ${ }^{3}$ Universidade do Minho, Campus de Gualtar, Braga, Portugal \\ Correspondence: Armando Mendes Jorge Nogueira Silva, Instituto Politécnico do Porto, ISCAP and CEFUP, Porto, \\ Portugal
}

Received: February 8, 2018

Accepted: February 25, 2018

Online Published: March 5, 2018

doi:10.5430/ijfr.v9n2p64

URL: https://doi.org/10.5430/ijfr.v9n2p64

\begin{abstract}
The purpose of this study is to analyze the degree of financial constraints faced by the companies included on the Portuguese Stock General Index when accessing to external financing, especially after the beginning and during the most recent financial crisis that affected the world financial markets from 2007. According to this aim, a longitudinal database is collected from the SABI database and was analyzed under panel data methodology. The final sample is panel data of 430 firm-year observations, related to 43 companies, during the period 2006-2015.

In line with previous literature, our results provide evidence that the payout ratio is an efficient measure of the degree of financial constraints; companies that pay out less (or no) dividends display higher sensitivity of the investment to the cash flow. Moreover, we also found that the investment sensitivity to cash flow intensifies immediately after and during the most recent financial crisis.
\end{abstract}

Keywords: financial contraints, investment, financial crisis, public firms

\section{Introduction}

The first hypothesis developed in the literature on external financing constraints' assessment is that the sensitivity of investment to internal financing, measured by cash flow, can be seen as a sign of financial constraints (Fazzari, Hubbard \& Peterson, 1988). However, this hypothesis remains controversial until now and the corresponding literature is quite mixed (eg, Kaplan \& Zingales, 1997). As financial constraints continue to be an abstract concept, since it can not be observed (Carreira \& Silva, 2010), researchers attempt to circumvent such "abstraction" by using different measures to assess the degree of financial constraints faced by firms as it is the use of several proxies, sensitivities or of long-term debt ratings (eg, Lamont, Polk \& Saa-Requejo, 2001; Whited \& Wu, 2006; Almeida, Campello \& Weisbach, 2004).

Nowadays, given the recent financial crisis that has shaken the world (the crisis of the US mortgage credit market known as subprime) it is expected that financial constraints may have increased and that the topic gained additional importance for the majority of firms. Such crisis triggered in 2007 has affected the world financial markets with consequences that were felt untill now. In Portugal, the financial crisis quickly became an economic crisis which produced its main negative effects until the end of 2012, as in 2013 the European Central Bank changed its monetary policies, which allowed the reversal of a recessionary economic cycle experienced in previous years.

In this context, the objective of this paper is to contribute to the discussion on the degree of financial restrictions faced by the group of listed companies that are part of the Portuguese Stock Index (PSI) and to evaluate the connections between such constraints and the crisis period aforementioned. According to these objectives, two research hypotheses were formulated, a database was collected and treated, an empirical methodology was defined and apllied; finally results that were discussed vis a vis the hypotheses in question.

Our results show that, in general, the dividend payout ratio has the capacity to capture the degree of financial constraints, since companies that pay less (or no) dividends present higher investment to cash flow sensitivity. 
Moreover, this connection seems to be intensified during the financial crisis period and shows a weaker sensitivity out of that time frame which is consistent with previous literature (Fazzari et al., 1988).

This paper is organized as follows. Section 2 presents literature review. Section 3 presents the two hypotheses to be tested and justifies the econometric methodology used. In Section 4 the database to be used is identified. In section 5 the models to be estimated are showed, the results obtained are interpreted and the hypotheses discussed. In the final chapter the main conclusions are presented.

\section{Theoretical Background}

Carreira and Silva (2010) define financial constraint as the inability of a company to access the necessary financing to take advantage of investment and growth opportunities. This inability is usually due to the difficulties firms encounter when trying to access external financing.

Although relatively easy to define, it's very hard to measure financial constraints. In this context, several previous studies (eg, Fazzari et al. (1988)) propose many alternatives for measuring financial constraints but the fact is that there is little consensus on this matter.

The seminal study of Fazzari et al. (1988) proposes as an indicator of the degree of financial constraints the dividend payout ratio. The authors hypothesize that companies considered to be financially constrained (with a low ratio of dividend distribution) present, on their investment, a greater sensitivity to the available cash flows. In the attempt to test such hypothesis the authors collected information for a sample of manufacturing companies listed on the US stock market during the period 1970-1984 and classified as financially constrained the firms which had a payout ratio of less than 10\% (in the last 10 years of the sample used). Their results exhibited evidence that companies which fail to distribute (or distribute few) dividends relative to available net income, in average, channel their cash flows for investment in real assets, compared to companies with the highest payout ratio of dividends, considered as not restricted. Thus, according to the evidence shown by Fazzari et al. (1988), companies with low or even non-existent dividend payout ratios feel more financial constrained and this situation means a greater sensitivity of their investment to the cash flow generated internally.

In line with Kaplan and Zingales (1997), all firms suffer from financial constraints, to a greater or lesser degree, given the difference between the cost of internal and external financing. Authors defend the argument that the cost of internal funds to be lower than the cost of external funds, meaning that these two sources of funding are not perfect substitutes, as argued by Modigliani and Miller (1958). The difference in the cost between internal and external funds can be explained, at least in part, by the costs of information asymmetry (Jensen \& Meckling, 1976); the greater the magnitude of information asymmetry, the higher the risk premium required by investors (shareholders and bondholders) and the higher will be the cost of capital.

The results obtained by Hubbard, Kashyap \& Whited (1995) are similar to those of Fazzari et al. (1988), since they analyzed the distribution of dividends with the same purpose of assessing the sensitivity of the investment to cash flow; both studies have shown that the companies with the highest dividend payout ratio belong to the group with the lowest financial restrictions. Those researches were followed by others that obtained similar results: Calomiris and Himmelberg (1995), Alti (2003), Bond, Elston, Mairesse \& Mulkay (2003), Boyle and Guthrie (2003), Love (2003) or Islam and Mozumdar (2007), among others.

Although framed in the general logic of Fazzari et al. (1988), some studies presented nuances on the form of measurement of firms' financial constraints. Bond and Meghir (1994), beyond the use of dividend payout ratios, also tested the issuance of stocks as a proxy of the financial restrictions. Along the same lines, Gilchrist and Himmelberg (1995) used the firm size and the existence of rating notation (of debt securities issued by the company) also as proxies of financial restrictions .

On the other side of this debate are the evidences of Kaplan and Zingales (1997). These authors argued that the model of investments'sensitivity to cash flow, proposed by Fazzari et al. (1988), was not a good measure of the external financing constraints. Kaplan and Zingales (1997) analyzed the same sample of 49 financially restricted companies that had been used in the study by Fazzari et al. (1988) and did not identify more than $15 \%$ of companies with difficulties in obtaining external financing. In fact, Kaplan and Zingales (1997) found that 85\% of these companies should not have been considered as restricted, since they had increased their investments through credit lines or cash reserves.

Several other studies presented were in line with the results of Kaplan and Zingales (1997) (e.g., Kadapakkam, Kumar \& Riddick, 1998, Cleary, 1999, Dasgupta \& Sengupta, 2007). Some of them (Erickson \& Whited, 2000; Gomes, 2001; Alti, 2003; Chen \& Chen, 2012) noticed the fact that the sensitivity of investment to cash flow may 
not be a good measure of financial constraints due to potential multicollinearity problems when including, in the same regression, the Tobin Q and the cash flow (as both variables capture growth opportunities).

In the long debate about the proper measurement of financial constraints, most of the studies present linear models of measurement and categorization of financial constraints. Lamont et al. (2001) developed an indicator of financial constraints based on results produced by Kaplan and Zingales (1997) called the KZ index. KZ index is a relative measure of dependence on external financing and is larger for narrower firms. The variables (signs) of $\mathrm{KZ}$ index are as follows: ratio between cash flow and fixed assets (negative); market to book ratio (positive); ratio between indebtedness and tangible fixed assets (positive); ratio between dividends and tangible fixed assets (negative); and the ratio of cash to cash equivalents and tangible fixed assets (negative). After the estimation of KZ index for each company, Lamont et al. (2001) formed portfolios, classifying all companies in each year according to the respective $\mathrm{KZ}$ index. In this way, $\mathrm{KZ}$ index is considered an efficient measure of financial constraints, since it is based on an in-depth study of companies. Given the nature of this indicator, companies with high KZ index have high debt, low cash and distribute little dividend in relation to their net result.

Meanwhile, other studies, including Whited and $\mathrm{Wu}$ (2006), argue that the $\mathrm{KZ}$ index presents problems in its construction and is not credible. In this way, Whited and $\mathrm{Wu}$ (2006) developed a measure of financial constraints based on accounting variables (cash flow, total assets, sales growth and dividend distribution). These authors constructed a new index of financial constraints using a structural investment model from an Euler equation. These authors have shown that companies classified as "restricted" have characteristics typically associated with exposure to external financial constraints; the firms considered to be "restricted" by the Whited and Wu (2006) index are small, under-investment sufferers, have low coverage by financial analysts, and do not have credit quality ratings. On the other hand, companies considered to be constrained by KZ index are large, showing overinvestment, have high coverage by analysts and possess a significantly higher incidence of quality rating of their debt than the rest of the business population

Also noteworthy are the studies by Hadlock and Pierce (2010), which propose a measure of financial constraints based on size and age of firms, and Musso and Schiavo (2008), which focused on the analysis of the financial constraints of exporting companies. In this context, Musso and Schiavo (2008) investigated information from seven different variables (comparing firms' performance with the performance of the sector, on the same indicator): size, profitability, liquidity, capacity to generate cash flow, solvency, trade credit and repayment capacity. The resulting information for each of the seven variables is then converted into an index by a simple arithmetic mean. The choice of the baseline variables to assess the level of financial rationing was performed because they were recognized as significant and correlated with the financial constraints in the previous literature. In addition, Musso and Schiavo (2008) argue that this methodology manages to capture different degrees of financial constraints and does not limit itself in dividing companies into "financially restricted" and "financially unrestricted". This measure of financial constraints although recent has been used by several authors (such as Bellone, Musso, Nesta \& Schiavo, 2010 or Silva, 2011).

The study on financial constraints is more imperious on times of economic and financial crisis when the offer of credit is lower and information asymmetry is higher. The last financial crisis was originated in the US in 2007 and was triggered by a poor credit phenomenon in the North American debt markets known as subprime; it rapidly jumped to the international scene in 2008. These events triggered a new wave of literature on financial constraints mainly devoted to the analysis of the diferences in levels of financial constraints before and in the aftermath of the financial crisis. In this line, Pinkowitz, Stuls \& Williamson (2013), argue that firms in the Eurozone countries (for a sample of 12 countries) have significantly increased their liquidity during (and even after) the financial crisis. The authors also established a comparative analysis between US companies and companies from other countries and showed evidence of an increase in liquidity reserves in companies based in the Euro Zone, still higher than that observed in US companies.

According to Campello, Graham \& Campbell (2010), during a financial crisis, companies face more severe limitations and restrictions on access to credit and also a global worsening of the terms and conditions of external financing (when compared to the pre-crisis period). In some Eurozone countries, such as Portugal, Greece and Ireland, the consecutive deterioration of sovereign debt rating has triggered severely the costs of access to external financing and the national banking institutions lost their capacity to finance themselves in the international banking system, which in turn affected the access to external financing by companies; this impact was felt not only by the smaller companies, but also had a significant impact on global business activity. 


\section{Hypothesis, Data and Empirical Model}

According to the previous literature review and given the main objective of this study, we propose to investigate the following hypotheses.

Hypothesis 1: The dividend payout ratio captures the degree of financial constraints.

Fazzari et al. (1988) argue that when firms rely more on cash flow to invest they tend to pay less dividends (or no dividends), and so the dividend payout ratio can be used as an adequate proxy to capture the level of financial constraints, since it indicates whether the company has sufficient internal funds to meet its financing needs.

Hypothesis 2: The sensitivity of investment to cash flow increases during the financial crisis.

This hypothesis lies on two assumptions; firstly, that the difference between the cost of domestic financing and the cost of external sources of financing depends on the asymmetry of information between a company; secondly, that in the middle of financial turmoils there is an increase on the general level of information asymmetry.

Given the main goal of this study is to analyze the financial constraints felt by the group of Portuguese companies listed on Euronext Lisbon during the period 2006 - 2015 and also to discuss the role of the financial crisis on such financial limitations, the sample collected consists of a longitudinal panel of data and given the heterogeneity of the sample, it is expected that the econometric methodology to apply to be a fixed effects model.

Econometric analysis of panel data can be affected by problems that bias the inferences, such as heteroscedasticity and autocorrelation. As a way of overcoming these problems, the clustering method is used to estimate robust standard errors, allowing a "limited" endogeneity, since it assumes that the observations of the same entity (company) can be correlated throughout the time period, while observations among different entities are not correlated with each other (Cameron \& Triverdi, 2009: 233). Moreover, this method of clustering can be applied individually (eg, by company or by country) or in a double way (by company and by year). The disadvantage of the double-clustering method is that it can not be combined with the fixed-effects methodology per company (due to the large number of entities), but can be applied in conjunction with the OLS method, controlling for other effects, for industry.

Furthermore, to test hypothesis 2 , in addition to the previously mentioned methodology, the difference-in-differences technique will be used; this methodology consists of estimating the differences between two observation groups belonging to the same sample. The objective of applying this technique is to estimate the differences between the restricted or non-restricted companies (in and out of crisis period) in what concerns all variables studied.

In order to divide the sample into financially constrained or non-financially constrained firms, two proxies of financial constraints were used: the dividend payout ratio and firm's size (this one is not reported). For each firm and year, we report if the payout ratio is below (or above) the median and in that case we classify the firm as financially constrained (not constrained) respectively.

As mentioned before, this study uses a longitudinal data panel that contains information for the group of companies listed on the Euronext Lisbon stock exchange. The necessary information (for the construction of the financial and accounting variables used in this study) wase collected from the SABI database. The sample period is from 2006 to 2015 but three subperiods were built: i) pre-crisis period from 2006 to 2008; ii) crisis period between 2009 and 2012; (iii) post-crisis period from 2013 to 2015 .

According to Almeida et al. (2004), financial firms (due to differences in accounting information construction) and companies in highly regulated sectors (such as the electricity sector) were excluded from the final sample. Moreover, observations with anomalies in their book values were eliminated (that's the case of punctual observations showing negative values in total assets, tangible fixed assets, intangible assets, cash and cash equivalents, total liabilities and market capitalization). Aditionally, in order to limit the influence of extreme values on coefficient estimates (which could generate bias on statistical inference), all variables underwent a winsorizing process of extreme values at the level of $0.5 \%$ in each tail of the distribution. After all this, the final sample is an unbalanced panel of data of 430 observations, for 43 companies, in the period 2006-2015.

In terms of the empirical model to use and given the objetives of the study, the data available and the previous literature (Fazzari et al., 1988; Almeida et al., 2004; Kaplan and Zingales (1997)), the following variables were selected in order to test the hypotheses previously formulated:

Dependent variable: Investment.

Two variables were adopted as proxies of the investment made in each year: 
- Investment (1): Ratio between investment expenses (known as capital expenditures or capex) and total assets measured at the beginning of the period;

- Investment (2): Percentage variation (annual) of total assets.

Independent variable: Cash Flow

Cash flow or domestic financing will be measured as the sum of net income, depreciations and amortizations, all divided by total assets, at the beginning of the period.

Control variables:

- Tobin's Q ratio: given the impossibility of using the true variable, it will be measured as the sum of market capitalization and liabilities, divided by total assets, at the beginning of the period.

- Dimension or Size: natural logarithm of the total assets.

- Industry: Classification by economic activity code according to Fama and French (1997); in this case given the small number of companies that compose the Portuguese stock exchange it was chosen to collect data only for 12 industries.

- GDP growth rate: This variable is used to capture temporal effects and data was collected at the World Bank.

- Crisis: Dummy variable that assumes the value of " 1 " in the portuguese years of more severe financial crisis (2009-2012) and value " 0 " in the other years.

- Payout ratio: dividends paid to shareholders over operating income (Earnings Before Interest and Taxes - EBIT)

Finally, to empirically test the two working hypothesis, we present the regression models apllied.

Firstly, according to our hypothesis 1, we assume that the dividend payout ratio captures the degree of financial constraints felt by the companies of the General PSI and thus it is an efficient measure of the degree of financial constraints faced by companies. Then, and in consonance with Fazzari et al. (1988), we defined the following models:

$$
\begin{aligned}
& \text { Inv }_{i, t}=\beta_{0}+\beta_{1} \text { Cash Flow }_{i, t-1}+\beta_{2} Q_{i, t-1}+\beta_{3} \text { Dimension }_{i, t}+\beta_{4} G D P_{t}+\gamma_{i}+\varepsilon_{i, t} \\
& \text { Inv }_{i, t}=\beta_{0}+\beta_{1} \text { Cash Flow }_{i, t-1}+\beta_{2} Q_{i, t-1}+\beta_{3} \text { Dimension }_{i, t}+\beta_{4} G D P_{t}+\mu_{i}+\varepsilon_{i, t}
\end{aligned}
$$

Where $\operatorname{Inv}_{\mathrm{i}, \mathrm{t}}$ is the investment dependent variable, which can be measured in two different ways, such as: i) Capext /Total Assetst-1 (Investment 1) and ii) the annual variation (percentage) of the investment in total assets (Investment 2); Cash Flow $\mathrm{i}_{\mathrm{t}-\mathrm{t}-1}$ is measured as the sum of net result, depreciations and amortizations all divided by total assets at the beginning of the period; $\mathrm{Q}_{\mathrm{i}, \mathrm{t}}$ is the sum of stock market capitalization and total assets, subtracted from the value of equity and divided by total assets, at the beginning of the period; Dimension ${ }_{i, t}$ is measured as the natural $\operatorname{logarithm}$ of the total assets; GDP $_{t}$ captures temporal effects; $\gamma_{i}$, represents an industrial code, according to Fama and French (1997), to control for the specifics of each industry; $\mu_{\mathrm{i}}$ is a term that captures unobserved heterogeneity when applied to the fixed effects methodology; $\varepsilon_{i}, \mathrm{t}$ is the error term.

Equation (1) is in agreement with the OLS method and will be tested using the OLS estimator and the double clustering method (per company and per year). Equation (2) will be tested as a fixed effects model, with cluster by company.

Meanwhile, hypothesis 2 postulates that the sensitivity of the investment to cash flow increases during the period of financial crisis, which means that companies financially constrained feel a worsening in the degree of restriction as a natural effect of a recessive economic cycle. Thus, the following equations have been specified in order to capture the differences in the relationship between investment proxies and cash flow during the crisis period and off that period.

$$
\begin{aligned}
& \text { Inv }_{i, t}=\beta_{0}+\beta_{1} \text { Cash Flow }_{i, t-1}+\beta_{2} \text { Cash Flow }_{i, t-1} \times \text { Crisis }+\beta_{3} \text { Crisis }+\beta_{4} Q_{i, t}+\beta_{5} \text { Dimension }_{i, t} \\
& +\beta_{6} G D P t+\gamma_{i}+\varepsilon_{i, t} \\
& \text { Inv }_{i, t}=\beta_{0}+\beta_{1} \text { Cash Flow }_{i, t-1}+\beta_{2} \text { Cash Flow }_{i, t-1} \times \text { Crisis }+\beta_{3} \text { Crisis }+\beta_{4} Q_{i, t}+\beta_{5} \text { Dimension }_{i, t} \\
& +\beta_{6} G D P_{t}+\mu_{i}+\varepsilon_{i, t}
\end{aligned}
$$

Where $\operatorname{Inv}_{\mathrm{i}, \mathrm{t}}$; Cash Flow $_{\mathrm{i},-1} ; \mathrm{Q}_{\mathrm{it}}$; Dimension $\mathrm{i}_{\mathrm{i}, \mathrm{t}} ; \mathrm{GDP}_{\mathrm{t}} ; \gamma_{\mathrm{i}} ; \mu_{\mathrm{i}} ; \varepsilon_{\mathrm{i}, \mathrm{t}}$ are defined as before. Crisis is a binary variable (dummy) that assumes the value " 1 " in the years between 2009 and 2012, and " 0 " in the other years; Cash Flow it $-1.1 \times$ Crisis is an interaction variable that corresponds to the multiplication of cash flow by the variable Crisis; this variable captures the sensitivity of the investment to cash flow only during the crisis years, for the groups of 
companies - restricted and unrestricted - according to the payout ratio. Thus, the sample is divided into financially restricted (or non-financially restricted) as each observation is below (or above) the median of the payout ratio.

Equation (3) will be tested using the OLS estimator without and with the double clustering method (per company and per year). Equation (4) will be tested with the fixed effects model, with cluster by company.

\section{Results and Discussion}

The first results displayed are the descriptive statistics of our sample (Table 1), as well as the differences between means and medians for the 3 sub-samples: i) before the financial crisis $(2006-2008)$; (ii) during the financial crisis (2009 - 2012); (iii) after the financial crisis (2013 - 2015). In Panel C of Table 1 results show more significant differences between averages and medians in the analysis of the Crisis / Pre-Crisis period than in the Crisis / Post-Crisis period, for the variables that measure the investment and the Tobin's Q ratio; such results of the univariate analysis suggest that the behavior of the variables did not change significantly between the crisis period and the post-crisis period.

Table 1. Descriptive statistics

\begin{tabular}{|c|c|c|c|c|c|c|c|c|c|}
\hline \multicolumn{10}{|c|}{ Panel A: Descriptive Statistics } \\
\hline Variables & $\mathrm{N}$ & Mean & \multicolumn{2}{|c|}{ Median } & \multicolumn{2}{|l|}{ S.D. } & Mín. & \multicolumn{2}{|c|}{ Max. } \\
\hline Investment 1 & 407 & 0,0465 & \multicolumn{2}{|c|}{0,0243} & \multicolumn{2}{|c|}{0,0633} & 0 & \multicolumn{2}{|c|}{0,3676} \\
\hline Investment 2 & 387 & 0,0486 & \multicolumn{2}{|c|}{$-0,0012$} & \multicolumn{2}{|c|}{0,3013} & $-0,7463$ & \multicolumn{2}{|c|}{2,6771} \\
\hline Dimension & 433 & 12,78 & \multicolumn{2}{|c|}{12,84} & \multicolumn{2}{|l|}{1,83} & 8,28 & \multicolumn{2}{|c|}{16,49} \\
\hline $\mathrm{CF}$ & 377 & 0,0635 & \multicolumn{2}{|c|}{0,0592} & \multicolumn{2}{|c|}{0.1045} & $-0,3658$ & \multicolumn{2}{|c|}{0,6448} \\
\hline Q & 351 & 1,2243 & \multicolumn{2}{|c|}{1,0503} & \multicolumn{2}{|c|}{1.2417} & -8.7248 & \multicolumn{2}{|c|}{8,2261} \\
\hline Payout & 362 & 3,3078 & \multicolumn{2}{|c|}{0,0017} & \multicolumn{2}{|c|}{14,62} & $-45,61$ & \multicolumn{2}{|c|}{122,05} \\
\hline GDP & 450 & $-0,0013$ & \multicolumn{2}{|c|}{0,0055} & \multicolumn{2}{|c|}{$-0,0400$} & 0,0212 & \multicolumn{2}{|c|}{0,0250} \\
\hline \multicolumn{10}{|c|}{ Panel B: Descriptive Statistics } \\
\hline \multirow[t]{2}{*}{ Variables } & $\mathrm{N}$ & Mean & Median & $\mathrm{N}$ & Mean & Median & $\mathrm{N}$ & Mean & Median \\
\hline & \multicolumn{2}{|c|}{ Pre-Crisis } & & Crisis & & & Post- & & \\
\hline Investment 1 & 112 & 0,0574 & 0,0345 & 163 & 0,0439 & 0,0223 & 132 & 0,0403 & 0,0219 \\
\hline Investment 2 & 82 & 0,2011 & 0,0532 & 173 & 0,0355 & $-0,0025$ & 132 & $-0,0289$ & $-0,0194$ \\
\hline Dimension & 124 & 12,72 & 12,78 & 177 & 12,85 & 12,86 & 132 & 12,75 & 12,85 \\
\hline $\mathrm{CF}$ & 80 & 0,0662 & 0,0687 & 171 & 0,0636 & 0,0513 & 126 & 0,0617 & 0,0601 \\
\hline Q & 70 & 1,5585 & 1,2814 & 156 & 1,1254 & 1,0248 & 125 & 1,1605 & 1,0132 \\
\hline Payout & 97 & 3,0664 & 0,0013 & 151 & 3,3135 & 0,0029 & 114 & 3,5056 & 0,0008 \\
\hline GDP & 135 & 0,0143 & 0,016 & 180 & $-0,0173$ & $-0,024$ & 135 & 0,0043 & 0,009 \\
\hline
\end{tabular}

Panel C: Mean Differences and Median Differences

\begin{tabular}{lllll}
\hline & \multicolumn{2}{c}{ Crisis/ Pre-Crisis } & \multicolumn{2}{c}{ Crisis/ Post-Crisis } \\
\hline \multirow{2}{*}{ Investment 1} & Mean Differences & Median Differences & Mean Differences & Median Differences \\
& $-0,0135^{*}$ & $-0,0122^{* *}$ & 0,0036 & 0,0004 \\
\multirow{2}{*}{ Investment 2 } & $(0,0975)$ & $(0.0445)$ & $(0,6100)$ & $(0,2828)$ \\
& $-0,1656^{* * *}$ & $-0,0557^{* * *}$ & $0,0644 * * *$ & $0,0169^{*}$ \\
Dimension & $(0,0048)$ & $(0.0013)$ & $(0,0053)$ & $(0,0664)$ \\
& 0,1353 & 0,0800 & 0,0993 & 0,0100 \\
CF & $(0,5333)$ & $(0.5386)$ & $(0,6360)$ & $(0,6889)$ \\
& $-0,0026$ & $-0,0174 *$ & 0,0019 & $-0,0088$ \\
& $(0,8493)$ & $(0,0605)$ & $(0,8803)$ & $(0,3455)$
\end{tabular}




\begin{tabular}{lllll}
$\mathrm{Q}$ & $-0,4332 * * *$ & $-0,2566 * * *$ & $-0,0352$ & 0,0116 \\
\multirow{2}{*}{ Payout } & $(0,0099)$ & $(0,0000)$ & $(0,8108)$ & $(0,3318)$ \\
& 0,2472 & 0,0016 & $-0,1921$ & 0,0021 \\
& $(0,8453)$ & $(0,7675)$ & $(0,9217)$ & $(0,8009)$
\end{tabular}

Notes: In Panel A, N is the number of observations, the mean and median are measures of central tendency, the S.D.is the standard deviation and the Min and Max are the respective minimum and maximum values recorded in each variable. Panel B reports the observation number $(\mathrm{N})$, the mean and median for the three subgroups in the sample: (i) before the financial crisis; (ii) during the financial crisis; (iii) after the financial crisis. Panel C reports the difference between mean and medians for each variable between two periods: Crisis / Pre-Crisis and Crisis / Post-Crisis, respectively. The mean difference is tested by a test $t$ of Student and the difference in medians is tested by a test $\mathrm{z}$ of Wilcoxon. $*, * *, * * *$ show the significance level at 10,5 and $1 \%$, respectively.

After this first descriptive analysis, we advance to the discussion of the regressions's coefficients of the four equations tested.

The results in Table 2 are the tests made to equations (1) and (2) which allow the validation of hypothesis 1; those results present evidence of a positive and statistically significant relationship between investment and cash flow, for the group of companies considered to be financially constrained; this result is robust to any of the proxies used to capture the degree of financial constraints (dividend payout ratio or dimension) and also for both proxies of investment. In fact, for the group of companies considered as not financially constrained, the relationship between investment and cash flow is not statistically significant.

For the remaining variables, the $\mathrm{Q}$ variable is positive and statistically significant, in most of the estimates, losing significance when the estimation method is a fixed effects model, which may mean that there are other unobservable characteristics that explain future investment opportunities. Regarding the dimension variable, the results show that an increase in firms'dimension (ceteris paribus) is associated with more investment but effects are not supported for all equations.

In short, the results documented in Table 2 suggest a positive and significant relationship between investment and cash flow, for the group of companies that distribute less (or no) dividends, which seems to support our hypothesis 1. This evidence confirms, in general terms, the results of Fazzari et al. (1988), where it is expected that firms pay less dividends to rely more on cash flow to invest.

Table 2. Regressions for equations (1) and (2)

\begin{tabular}{|c|c|c|c|c|c|c|c|c|c|c|c|c|}
\hline \multicolumn{13}{|c|}{ Panel A - Investment 1} \\
\hline & 1 & 2 & 3 & 4 & 5 & 6 & 7 & 8 & 9 & 10 & 11 & 12 \\
\hline \multirow{2}{*}{$\begin{array}{c}\text { Model } \\
\begin{array}{c}\text { Dependent } \\
\text { Variable }\end{array} \\
\end{array}$} & oLs & oLs & oLS & oLs & $\begin{array}{l}\text { DOUBLE } \\
\text { CLUSTR }\end{array}$ & $\begin{array}{l}\text { DOLBLE } \\
\text { CLUSTR }\end{array}$ & $\begin{array}{l}\text { DOUBLE } \\
\text { CLUSTR }\end{array}$ & $\begin{array}{l}\text { DOUBLE } \\
\text { CLUSTR }\end{array}$ & $\mathrm{FE}$ & $\mathrm{FE}$ & $\mathrm{FE}$ & $\mathrm{FE}$ \\
\hline & \multicolumn{12}{|c|}{ 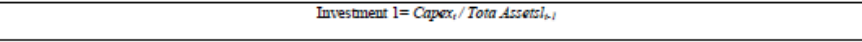 } \\
\hline Proxy & \multicolumn{2}{|c|}{ Dividends } & \multicolumn{2}{|c|}{ Dimension } & \multicolumn{2}{|c|}{ Dividends } & \multicolumn{2}{|c|}{ Dimension } & \multicolumn{2}{|c|}{ Dividends } & \multicolumn{2}{|c|}{ Dimension } \\
\hline $\begin{array}{c}\text { Level of } \\
\text { Constraint }\end{array}$ & NC & c & $\mathrm{NC}$ & c & NC & c & NC & $\mathrm{c}$ & $\mathrm{NC}$ & $\mathrm{c}$ & $\mathrm{NC}$ & c \\
\hline \multirow[t]{2}{*}{ CF } & 0,0883 & $0,106^{* t *}$ & 0,1000 & $0,1583^{* *}$ & 0,0883 & $0,1066^{* * *}$ & 0,1000 & $0,1583^{* *}$ & 0,0082 & 0,0106 & $-0,020$ & $0,049^{*}$ \\
\hline & $(1,34)$ & $(2,92)$ & $(1,65)$ & $(2,58)$ & $(0,94)$ & $(2,93)$ & $(1,71)$ & $(1,99)$ & $(0,10)$ & $(0,25)$ & $(-0,48)$ & $(1,89)$ \\
\hline \multirow[t]{2}{*}{ Q } & $0,0348 * * *$ & $0,014^{* * *}$ & $0,022^{\star \star * *}$ & $0,0218 \cdots$ & $0,0348^{\star \cdots *}$ & $0,0144^{*}$ & $0,0223^{* * *}$ & $0,0218^{* *}$ & 0,0016 & $-0,001$ & $-0,004$ & 0,0055 \\
\hline & $(4,48)$ & $(2,94)$ & $(2,70)$ & $(3,32)$ & $(4,24)$ & $(1,93)$ & $(3,51)$ & $(2,19)$ & $(0,40)$ & $(-0,34)$ & $(-0,98)$ & $(1,59)$ \\
\hline \multirow[t]{2}{*}{ Dimension } & $0,0063 \cdots * *$ & $0,0052^{*}$ & $0,0046^{*}$ & $0,0070^{* *}$ & $0,0063 * *$ & 0,0052 & 0,0046 & $0,0070^{*}$ & $-0,003$ & 0,0059 & $-0,006$ & $-0,001$ \\
\hline & $(2,93)$ & $(1,82)$ & $(1,71)$ & $(2,61)$ & $(2,56)$ & $(0,99)$ & $(0,96)$ & $(1,82)$ & $(-0,15)$ & $(0,43)$ & $(-0,18)$ & $(-0,10)$ \\
\hline \multirow[t]{2}{*}{ GDP } & $-0,1798$ & 0,0520 & 0,0460 & $-0,2695$ & $-0,1798$ & 0,0520 & 0,0460 & $-0,2695$ & $-0,034$ & 0,1111 & 0,1847 & $-0,091$ \\
\hline & $(-0,99)$ & $(0,32)$ & $(0,29)$ & $(-1,32)$ & (). & $(0,46)$ & $(0,53)$ & $(-1,34)$ & $(-0,36)$ & $(0,98)$ & $(1,43)$ & $(-0,40)$ \\
\hline \multirow[t]{2}{*}{ Constant } & $-0,109 * \cdots$ & $-0,069 * *$ & $-0,074^{* *}$ & $-0,097 * \cdots$ & $-0,109 * \cdots$ & $-0,0693$ & $-0,0745$ & $-0,0978^{*}$ & 0,0793 & $-0,028$ & 0,1330 & 0,0483 \\
\hline & $(-3,65)$ & $(-2,00)$ & $(-2,06)$ & $(-2,73)$ & $(-2,96)$ & $(-1,02)$ & $(-1,25)$ & $(-1,75)$ & $(0,33)$ & $(-0,16)$ & $(0,30)$ & $(0,37)$ \\
\hline Observations & 123 & 216 & 178 & 161 & 123 & 216 & 178 & 161 & 123 & 216 & 178 & 161 \\
\hline $\mathbf{R}^{2}$ & 0,603 & 0,268 & 0,447 & 0,302 & 0,603 & 0,268 & 0,447 & 0,302 & 0,002 & 0,007 & 0,032 & 0,024 \\
\hline
\end{tabular}




\begin{tabular}{|c|c|c|c|c|c|c|c|c|c|c|c|c|}
\hline \multicolumn{13}{|c|}{ at 2} \\
\hline \multirow{3}{*}{$\begin{array}{c}\text { Model } \\
\begin{array}{c}\text { Dependent } \\
\text { variable }\end{array}\end{array}$} & 1 & 2 & 3 & 4 & 5 & 6 & 7 & 8 & 9 & 10 & 11 & 12 \\
\hline & \multirow[t]{2}{*}{ OLS } & \multirow[t]{2}{*}{ OLS } & \multirow[t]{2}{*}{ OLS } & \multirow[t]{2}{*}{ oLs } & $\begin{array}{l}\text { DOUBL } \\
\text { CLUSTR }\end{array}$ & $\begin{array}{l}\text { DOUBL } \\
\text { CLUSTR }\end{array}$ & \multicolumn{2}{|c|}{$\begin{array}{l}\text { DOUBL } \\
\text { DOUBRL } \\
\text { CLUSTR }\end{array}$} & FE & $\mathrm{FE}$ & \multirow[t]{2}{*}{$\mathrm{FE}$} & \multirow[t]{2}{*}{$\mathrm{FE}$} \\
\hline & & & & & & $2=$ Percen & ual variatio & of Total As & & & & \\
\hline Proxy & \multicolumn{2}{|c|}{ Dividends } & \multicolumn{2}{|c|}{ Dimension } & \multicolumn{2}{|c|}{ Dividends } & \multicolumn{2}{|c|}{ Dimension } & \multicolumn{2}{|c|}{ Dividends } & \multicolumn{2}{|c|}{ Dimension } \\
\hline $\begin{array}{c}\text { Level of } \\
\text { Constraint }\end{array}$ & NC & c & NC & c & NC & $\mathrm{c}$ & NC & c & NC & c & NC & c \\
\hline \multirow[t]{2}{*}{ CF } & $-0,1395$ & $0,64^{* * *}$ & 0,4270 & $0,913^{* *}$ & $-0,1395$ & $0,642^{\ldots \ldots t}$ & 0,4270 & $0,9131^{* t}$ & 0,3428 & $0,5385^{* *}$ & 1,0772 & 0,834 \\
\hline & $(-0,29)$ & $(3,02)$ & $(1,46)$ & $(2,53)$ & $(-0,31)$ & $(2,65)$ & $(1,17)$ & $(2,36)$ & $(0,70)$ & $(2,35)$ & $(1,48)$ & $(2,01)$ \\
\hline \multirow[t]{2}{*}{ Q } & $0,219 *$ & $0,06^{* * *}$ & $0,091 *$ & $0,106^{* *}$ & 0,2197 & $0,059 \ldots$ & $0,0910^{*}$ & $0,1063^{* *}$ & $0,494 * \ldots$ & $0,057 * * *$ & $0,1928^{*}$ & $0,0987^{*}$ \\
\hline & $(2,42)$ & $(4,16)$ & $(2,60)$ & $(2,32)$ & $(1,63)$ & $(4,65)$ & $(1,83)$ & $(2,01)$ & $(3,36)$ & $(2,93)$ & $(1,87)$ & $(1,83)$ \\
\hline \multirow[t]{2}{*}{ Dimension } & 0,0263 & 0,0050 & 0,0064 & 0,0102 & 0,0263 & 0,0050 & 0,0064 & 0,0102 & $0,424 * \ldots$ & $0,182^{\star * * *}$ & $0,694 * \cdots$ & $0,1636^{*}$ \\
\hline & $(1,26)$ & $(0,49)$ & $(0,38)$ & $(0,87)$ & $(0,99)$ & $(0,44)$ & $(0,32)$ & $(0,62)$ & $(3,53)$ & $(4,88)$ & $(3,50)$ & $(2,00)$ \\
\hline \multirow[t]{2}{*}{ GDP } & 0,9164 & 0,5843 & 1,0040 & 0,4455 & 0,9164 & 0,5843 & $1,0040^{* * *}$ & 0,4455 & $-0,1109$ & 0,9591 & 0,1031 & $1,3346^{\circ}$ \\
\hline & $(0,75)$ & $(0,93)$ & $(1,29)$ & $(0,52)$ & $(1,04)$ & $(0,80)$ & $(2,39)$ & $(0,54)$ & $(-0,11)$ & $(1,62)$ & $(0,18)$ & $(1,71)$ \\
\hline \multirow[t]{2}{*}{ Constant } & $-0,433^{*}$ & $-0,1982$ & 0,0488 & $-0,393 * *$ & $-0,4328$ & $-0,1982$ & 0,0488 & $-0,3926$ & $-6,09 * \ldots$ & $-2,43 * * *$ & $-9,38^{* * *}$ & $-2,203^{* *}$ \\
\hline & $(-1,82)$ & $(-1,65)$ & $(0,23)$ & $(-2,05)$ & $(-1,03)$ & $(-1,25)$ & $(0,23)$ & $(-1,51)$ & $(-3,80)$ & $(-5,27)$ & $(-3,68)$ & $(-2,16)$ \\
\hline Observations & 123 & 223 & 179 & 167 & 123 & 223 & 179 & 167 & 123 & 223 & 179 & 167 \\
\hline $\mathbf{R}^{2}$ & 0,307 & 0.218 & 0,179 & 0,258 & 0.307 & 0,218 & 0,179 & 0.258 & 0,604 & 0,274 & 0,380 & 0,264 \\
\hline
\end{tabular}

Notes: Table 2 presents the regression coefficients of estimations for different specifications of equations (1) and (2), depending on the dependent variable, the regression method and the proxy that captures the financial constraints. Two proxies of financial constraints are used, the dividend payout ratio and dimension. The sample is divided into either financiallly constrained (C) or unconstrained (NC) as each observation is below or above the median, respectively, of each of the proxies. Panel A reports the results for the dependent variable Investment 1, Panel B reports the results for the dependent variable Investment 2 . The variables are as described before. The values in parentheses refer to results of the statistical test of significance of the coefficients. The statistical tests of OLS and Fixed Effect regression coefficient estimates are based on robust standard errors for company and year groupings and only per company, respectively. *,**,*** indicates the level of significance at 10,5 and $1 \%$, respectively. Models 1 , 2, 3 and 4 are OLS models. Models 5, 6, 7 and 8 are dual cluster OLS models. The models 9, 10,11 and 12 are fixed effects models (FE).

In what concerns hypothesis 2, models 1 and 2 presented in Table 3 are OLS regression models. Models 3 and 4 are OLS regression models, but with a double cluster (per company and per year). Models 5 and 6 are fixed effects models with cluster by company.

Table 3. Regressions for equations (3) and (4)

\begin{tabular}{lllllll}
\hline \multicolumn{7}{c}{ Panel A } \\
\hline Model & $\mathbf{1}$ & $\mathbf{2}$ & $\mathbf{3}$ & $\mathbf{4}$ & $\mathbf{5}$ & $\mathbf{6}$ \\
\hline Dependent variable & OLS & OLS & $\begin{array}{l}\text { DOUBLE } \\
\text { CLUSTER }\end{array}$ & $\begin{array}{l}\text { DOUBLE } \\
\text { CLUSTER }\end{array}$ & FE & \multirow{2}{*}{ FE } \\
\hline Proxy & Investment & Capex /Ativo & Total $_{t-1}$ \\
\hline Level of Constraint & DC & C & NC & C & NC & C \\
\hline CF & 0,1885 & 0,0044 & 0,1885 & 0,0044 & 0,0177 & 0,0095 \\
& $(1,60)$ & $(0,09)$ & $(1,13)$ & $(0,11)$ & $(0,15)$ & $(0,14)$ \\
CF*Crisis & $-0,1780$ & $0,1622^{* *}$ & $-0,1780$ & $0,1622^{* *}$ & 0,0129 & $-0,0266$ \\
& $(-1,39)$ & $(2,15)$ & $(-1,08)$ & $(2,52)$ & $(0,09)$ & $(-0,22)$ \\
Crisis & 0,0155 & 0,0039 & 0,0155 & 0,0039 & 0,0198 & 0,0103 \\
& $(1,16)$ & $(0,41)$ & $(0,95)$ & $(0,46)$ & $(0,94)$ & $(0,92)$ \\
Q & $0,0335^{* * *}$ & $0,0163^{* * *}$ & $0,0335^{* * *}$ & $0,0163^{* *}$ & $-0,0003$ & $-0,0016$ \\
& $(4,24)$ & $(3,28)$ & $(4,12)$ & $(2,52)$ & $(-0,07)$ & $(-0,34)$
\end{tabular}




\begin{tabular}{|c|c|c|c|c|c|c|}
\hline \multirow[t]{2}{*}{ Dimension } & $0,0067 * * *$ & \multicolumn{2}{|r|}{$0,0067 * * *$} & 0,0043 & $-0,0098$ & \multirow{2}{*}{$\begin{array}{l}0,0031 \\
(0,27)\end{array}$} \\
\hline & $(3,09)$ & $(1,48)$ & $(2,66)$ & $(0,82)$ & $(-0,49)$ & \\
\hline \multirow[t]{2}{*}{ GDP } & $-0,1355$ & 0,2280 & $-0,1355^{* * *}$ & 0,2280 & 0,2072 & $0,2154^{*}$ \\
\hline & $(-0,62)$ & $(1,29)$ & $(-2,70)$ & $(1,21)$ & $(1,09)$ & $(1,92)$ \\
\hline \multirow[t]{2}{*}{ Constant } & $-0,1209 * * *$ & $-0,0621^{*}$ & $-0,1209 * * *$ & $-0,0621$ & 0,1614 & 0,0035 \\
\hline & $(-3,76)$ & $(-1,73)$ & $(-2,74)$ & $(-0,96)$ & $(0,65)$ & $(0,02)$ \\
\hline \multirow[t]{2}{*}{$\mathrm{CF}+\mathrm{CF} * \mathrm{Crisis}$} & 0,0105 & 0,1666 & 0,0105 & 0,1666 & 0,0306 & $-0,0171$ \\
\hline & $(0,1272)$ & $(0,1805)$ & $(0,2623)$ & $(0,1149)$ & $(0,9845)$ & $(0,8439)$ \\
\hline Observations & 123 & 216 & 123 & 216 & 123 & 216 \\
\hline $\mathbf{R}^{2}$ & 0,612 & 0,295 & 0,612 & 0,295 & 0,063 & 0,019 \\
\hline \multicolumn{7}{|c|}{ Panel B } \\
\hline & 1 & 2 & 3 & 4 & 5 & 6 \\
\hline Model & OLS & OLS & $\begin{array}{l}\text { DOUBLE } \\
\text { CLUSTER } \\
\end{array}$ & $\begin{array}{l}\text { DOUBLE } \\
\text { CLUSTER } \\
\end{array}$ & $\mathbf{F E}$ & $\mathbf{F E}$ \\
\hline Dependent variablee & \multicolumn{6}{|c|}{ Investment 2 = Percentual variation of Total Assets } \\
\hline Proxy & \multicolumn{6}{|l|}{ Dividends } \\
\hline Level of Constraint & $\mathrm{NC}$ & $\mathrm{C}$ & $\mathrm{NC}$ & $\mathrm{C}$ & $\mathrm{NC}$ & $\mathrm{C}$ \\
\hline \multirow[t]{2}{*}{$\mathbf{C F}$} & $-0,6859$ & 0,5964 & $-0,6859$ & 0,5964 & 0,6241 & 0,2373 \\
\hline & $(-0,91)$ & $(1,52)$ & $(-0,62)$ & $(1,35)$ & $(0,95)$ & $(1,24)$ \\
\hline \multirow[t]{2}{*}{ CF*Crisis } & 1,1106 & 0,0720 & 1,1106 & 0,0720 & $-0,4945$ & $0,5158^{* *}$ \\
\hline & $(1,36)$ & $(0,16)$ & $(0,85)$ & $(0,16)$ & $(-0,72)$ & $(2,15)$ \\
\hline \multirow[t]{2}{*}{ Crisis } & 0,1147 & $0,0769 *$ & 0,1147 & $0,0769 * *$ & 0,0688 & $0,0607 *$ \\
\hline & $(1,36)$ & $(1,89)$ & $(0,95)$ & $(2,17)$ & $(1,19)$ & $(1,84)$ \\
\hline \multirow[t]{2}{*}{$\mathbf{Q}$} & $0,2296^{* *}$ & $0,0586 * * *$ & $0,2296^{*}$ & $0,0586^{* * *}$ & $0,4890 * * *$ & $0,0644 * * *$ \\
\hline & $(2,58)$ & $(3,90)$ & $(1,72)$ & $(4,79)$ & $(3,34)$ & $(3,56)$ \\
\hline \multirow[t]{2}{*}{ Dimension } & 0,0199 & 0,0042 & 0,0199 & 0,0042 & $0,4112 * * *$ & $0,1853 * * *$ \\
\hline & $(0,98)$ & $(0,41)$ & $(0,96)$ & $(0,35)$ & $(3,29)$ & $(6,74)$ \\
\hline \multirow[t]{2}{*}{ GDP } & $3,1143 * *$ & $1,5922 *$ & 3,1143 & $1,5922 * * *$ & 0,3023 & $2,0833 * * *$ \\
\hline & $(2,24)$ & $(1,96)$ & $(1,60)$ & $(4,50)$ & $(0,27)$ & $(2,81)$ \\
\hline \multirow[t]{2}{*}{ Constant } & $-0,4487 *$ & $-0,2207^{*}$ & $-0,4487$ & $-0,2207$ & $-5,9766 * * *$ & $-2,4994 * * *$ \\
\hline & $(-1,80)$ & $(-1,78)$ & $(-1,13)$ & $(-1,25)$ & $(-3,56)$ & $(-7,26)$ \\
\hline \multirow[t]{2}{*}{$\mathrm{CF}+\mathrm{CF}^{*} \mathrm{Crisis}$} & 0,4247 & 0,6684 & 0,4247 & 0,6684 & 0,1296 & 0,7531 \\
\hline & $(0,2325)$ & $(0,5247)$ & $(0,4551)$ & $(0,5424)$ & $(0,3739)$ & $(0,4682)$ \\
\hline Observations & 123 & 223 & 123 & 223 & 123 & 223 \\
\hline $\mathbf{R}^{2}$ & 0,351 & 0,243 & 0,351 & 0,243 & 0,608 & 0,324 \\
\hline
\end{tabular}

Notes: Table 3 shows the coefficients estimates of regressions for different specifications of equations (3) and (4), depending on the dependent variable, the regression method and the proxy that captures the financial constraints (dividend payout ratio). The sample is divided into either restricted (C) or non-restricted (NC) financially as each 
observation is below or above, respectively, the median of the dividend distribution ratio. Panel A reports the results for the dependent variable Investment1, Panel B reports the results for the dependent variable Investment 2 . The variables are those described in table 2 and crisis is a dummy variable already explained before. The values in parentheses report the results of the statistical test of significance of the coefficients. The statistical tests of OLS and Fixed Effect regression coefficient estimates are based on robust standard errors for company and year groupings and only per company, respectively. $* * *, * * *$ indicates the level of significance at 10,5 and $1 \%$, respectively. Models 1 and 2 are OLS models. Models 3 and 4 are dual cluster OLS models. Models 5 and 6 are fixed effects models (FE).

As expected, the relationship between investment and cash flow for companies considered as restricted according to the payout ratio is positive and significant for most of the coefficients, as can be seen in models (2) and (4) of Panels A and in model (6) of Panel B. These results complement the evidence shown in Table 2: the companies classified as financially restricted reflect a high sensitivity of the investment to domestic financing, that is, to their cash flow, and the degree of restriction increases after the start and during the financial crisis. Thus, hypothesis 2 seems to be supported by the results of Table 3 .

These evidences are aligned with the intuition of Fazzari et al. (1988); it is expected that the investment of companies facing more financial constraints will increase their sensitivity to cash flow especially at times when this cash flow is more volatile.

\section{Conclusions}

This paper had the goal to evaluate the restrictions on the access to external financing felt by the group of portuguese companies that belong to the General PSI of Euronext Lisbon; and such evaluation would be made both during the most recent financial crisis, and off that period. For that purpose, we collected a longitudinal panel of data, composed of 430 observations for 43 companies between 2006 and 2015.

Using both OLS and fixed effects models combined with a difference in diferences method, our results demonstrate evidence that the dividend distribution ratio is an efficient measure of the degree of financial constraints, since the companies that pay less (or no) dividends present a greater sensitivity of their investment to own internal financing, that is, to their cash flow; this result is robust to different investment measures and regression methods. Moreover, it was also possible to observe that this sensitivity of investment to cash flow is intensified during periods of financial crisis.

The research here produced tries to overcome a general lack of studies concerning portuguese firms' investment dependence on internal financing and in future studies should be extended to more firms and to a wider list of proxies measuring financial constraints.

Given the high dependence of Portuguese companies on bank financing and trade credit, this type of research proves importante, for people in charge with the investment promotion policies, to perceive the financing difficulties felt by the majority of Portuguese companies. Moreover, this vicious cycle of financial constraints - poor investment - more financial constraints is one of the main explanations for the inability of companies to grow and become more profitable by taking advantage of good investments opportunities.

\section{References}

Almeida, H., Campello, M., \& Weisbash, M. (2004). The Cash Flow Sensitivity of Cash. Journal of Finance, 59(4), 1777-1804. https://doi.org/10.1111/j.1540-6261.2004.00679.x

Alti, A. (2003). How Sensitive is Investment to Cash Flow when Financing is Frictionless?. Journal of Finance, 58(2), 707-722. https://doi.org/10.1111/1540-6261.00542

Bellone, F., Musso, P., Nesta, L., \& Schiavo, S. (2010). Financial Constraints and Firm Export Behaviour. The World Economy, 33(3), 347-373. https://doi.org/10.1111/j.1467-9701.2010.01259.x

Bond, S., \& Meghir, C. (1994). Dynamic Investment Models and the Firm's Financial Policy. Review of Economic Studies, 61(2), 197-222. https://doi.org/10.2307/2297978

Bond, S., Elston, J., Mairesse, J., \& Mulkay, B. (2003). Financial Factors And Investment in Belgium, France, Germany, and The United Kingdom: A Comparison Using Company Panel Data. Review of Economics And Statistics, 85(1), 153-165. https://doi.org/10.1162/003465303762687776

Boyle, G., \& Guthrie, G. (2003). Investment, Uncertainty, and Liquidity. Journal of Finance, 58, 2143-2166. https://doi.org/10.1111/1540-6261.00600 
Calomiris, C., \& Himmelberg, C. (1995). Investment Banking Costs as a Measure of Acess to External Finance. Manuscript. Columbia University.

Cameron, A., \& Triverdi, P. (2009). Microeconomics using Stata. Texas: Stata Press.

Campello, M., Graham, J., \& Campbell, H. (2010). The real effects of financial constraints: Evidence from a financial crisis. Journal of Financial Economics, 97, 470-487. https://doi.org/10.1016/j.jfineco.2010.02.009

Chen, H., \& Chen, S. (2012). Investment-Cash Flow Sensitivity Cannot be a Good Measure of Financial Constraints: Evidence from the Time Series. Journal of Financial Economics, 103, 393-410. https://doi.org/10.1016/j.jfineco.2011.08.009

Cleary, S. (1999). The Relationship between Firm Investment and Financial Status. Journal of Finance, 54(2), 673-692. https://doi.org/10.1111/0022-1082.00121

Cleary, S., Povel, P., \& Raith, M. (2007). The U-Shaped Investment Curve: Theory and Evidence. Journal of Financial and Quantitative Analysis, 42(1), 1-39. https://doi.org/10.1017/S0022109000002179

Dasgupta, S., \& Sengupta, K. (2007). Financial Constraints, Hurdle Rates, and Economic Activity: Implications from a Multi-Period Model. Journal of Financial Intermediation, 16, 151-174.

Erickson, T., \& Whited, T. (2000). Measurement Error and the Relationship Between Investment and Q. Journal of Political Economy, 108, 1027-1057. https://doi.org/10.1086/317670

Fama, E., \& French, K. (1997). Industry costs of equity. Journal of Financial Economics, 153-193.

Fazzari, S., Hubbard, R., \& Petersen, B. (1988). Financing Constraints and Corporate Investment. Brookings Papers on Economic Activity, 1, 141-206. https://doi.org/10.2307/2534426

Gilchrist, S., \& Himmelberg, C. (1995). Evidence on the Role of Cash Flow for Investment. Journal of Monetary Economics, 36, 541-572. https://doi.org/10.1016/0304-3932(95)01223-0

Gomes, J. (2001). Financing Investment. American Economic Review, 91, 1263-85. https://doi.org/10.1257/aer.91.5.1263

Guariglia, A. (2008). Internal Financial Constraints, External Financial Constraints, and Investment Choice: Evidence from a Panel of UK Firms. Journal of Banking and Finance, 32(9), 1795-1809. https://doi.org/10.1016/j.jbankfin.2007.12.008

Hadlock, C., \& Pierce, J. (2010). New Evidence on Measuring Financial Constraints: Moving Beyond the KZ Index. Review of Financial Studies, 23(5), 1909-1940. https://doi.org/10.1093/rfs/hhq009

Hubbard, R., Kashyap, A., \& Whited, T. (1995). Internal Finance and Firm Investment. Journal of Money Credit and Banking, 25, 683-701. https://doi.org/10.2307/2077743

Islam, S., \& Mozumdar, A. (2007). Financial Market Development and the Importance of Internal Cash: Evidence from International Data. Journal of Banking and Finance, 31(3), 641-658.

Jensen, M., \& Meckling, M. (1976). The Theory of the Firm: Managerial Behavior, Agency Costs, and Ownership Structure. Journal of Financial Economics, 4, 305-360. https://doi.org/10.1016/0304-405X(76)90026-X

Kadapakkam, P., Kumar, P., \& Riddick, L. (1998). The Impact of Cash Flows and Firm Size on Investment: The International Evidence. Journal of Banking and Finance, 22, 293-320.

Kaplan, S., \& Zingales, L. (1997). Do Investment Cash-Flow Sensitivities Provide Useful Measures of Financing Constraints. Quarterly Journal of Economics, 112(1), 169-215. https://doi.org/10.1162/003355397555163

Keynes, J. (1936). The General Theory of Employment. In Interest and Money. London: Macmillan and co. Limited.

Lamont, O., Polk, C., \& Saa-Requejo, J. (2001). Financial Constraints and Stock Returns. Quarterly Journal of Economics, 115, 707-712. https://doi.org/10.1093/rfs/14.2.529

Love, I. (2003). Financial Development and Financing Constraints: International Evidence from the Structural Investment Model. Review of Financial Studies, 16(3), 765-791. https://doi.org/10.1093/rfs/hhg013

Lyandres, E. (2007). Costly External Financing, Investment Timing, and Investment-Cash Flow Sensitivity. Journal of Corporate Finance, 13(5), 959-980. https://doi.org/10.1016/j.jcorpfin.2007.07.001

Modigliani, F., \& Miller, M. (1958). The Cost of Capital, Corporation Finance and the Theory of Investment. American Economic Review, 48(3), 261-297. 
Musso, P., \& Schiavo, S. (2008). The Impact of Financial Constraints on Firm Survival and Growth. Journal of Evolutionary Economics, 18(2), 135-149. https://doi.org/10.1007/s00191-007-0087-z

Pinkowitz, L., Stulz, R. M., \& Williamson, R. (2013). Is there a U.S. high cash holdings puzzle after the financial crisis? Charles A. Dice Center for Research in Financial Economics. Working Paper Series 2013-07. Ohio State University, Fisher College of Business.

Silva, A. (2011). Financial Constraints and Exports: Evidence from Portuguese Manufacturing Firms. International Journal of Economic Sciences and Applied Research, 4(3), 7-19.

Silva, F., \& Carreira, C. (2011). Financial Constraints and Exports: An Analysis of Portuguese Firms During the European Monetary Integration. GEE Working Papers N. 39, Office of Strategy and Research, Ministry of Economy and Innovation. Coimbra: GEMF, University of Coimbra - Faculty of Economics.

Tobin, J., \& Brainard, W. (1968). Pitfalls in Financial Model Building. American Economic Review, 58(2), 99-122.

Whited, T., \& Wu, G. (2006). Financial Constraints Risk. Review of Financial Studies, 19(2), 33-72. 